\title{
Kajian Yuridis Legalisasi Aborsi Bagi Korban Tindak Pidana Pemerkosaan dalam Perspektif Hukum Positif
}

\author{
Evi Yanti \\ Magister Ilmu Hukum Universitas Islam Indonesia Yogyakarta Indonesia \\ Jln. Cik Di Tiro No. 1, Yogyakarta 55223 Indonesia \\ evi.yanti1228@gmail.com
}

\begin{abstract}
Conflicts regarding the legalization of abortion occur because of the gap between one legislation and another. The problems in this study are: first, how to legalize abortion for victims of rape in the perspective of positive law; Second, as well as the legal protection for doctors and patients who perform such abortions. Women who get pregnant for becoming rape victims choose abortion as a way to end their pregnancy are deemed as perpetrators of the crime of abortion In the criminal law literature The research method used is a normative juridical method with an approach to legislation and comparative studies. The results of this study are first, abortion is a prohibited act, but if it is in an emergency situation and the victim is raped, abortion can be undertaken; second, legal protection for victims includes; a. The provision of medical and psychosocial assistance services to rape victims who have abortions in accordance with applicable laws and regulations as described in Article 6 of Law no. 13 of 2006 on the Protection of Witnesses and Victims; $b$. The compensation provided by the perpetrator is in accordance with the provisions of Article 7 paragraph (1) letter $b$ of Law No. 13 of 2006 on the Protection of Witnesses and Victims; $c$. Restitution, compensation given by the state because the perpetrator is unable. it is possible as an effort to provide services to victims of crime in the context of developing welfare and justice in accordance with the provisions of Article 7 paragraph (2) of Law No.r 13 of 2006 on the Protection of Witnesses and Victims.
\end{abstract}

Key Words : Legalization; abortion; rape victims

\begin{abstract}
Abstrak
Pertentangan mengenai legalisasi aborsi terjadi karena adanya kesenjangan antar peraturan perundangundangan yang satu dengan yang lainnya. Hal yang menjadi permasalahan dalam penelitian ini adalah pertama, bagaimana legalisasi aborsi bagi korban tindak pidana pemerkosaan dalam perspektif hukum positif? Kedua, bagaimana perlindungan hukum bagi dokter dan pasien dalam yang melakukan tindakan aborsi? Perempuan sebagai korban perkosaan yang hamil dan kemudian memilih aborsi sebagai cara untuk mengakhiri kehamilannya tersebut dikatakan sebagai pelaku tindak pidana aborsi. Dalam kepustakaan hukum pidana disebut dengan tindak pidana "pengguguran kandungan". Metode penelitian yang digunakan adalah metode yuridis normatif dengan pendekatan perundang-undangan dan studi komparatif. Adapun hasil penelitian ini menyimpulkan pertama, aborsi merupakan perbuatan yang dilarang, namun apabila dalam kondisi darurat dan korban hasil perkosaan aborsi dapat dilakukan; kedua, perlindungan hukum pada korban meliputi; a. Pemberian pelayanan bantuan medis dan psikososial kepada korban perkosaan yang melakukan aborsi sesuai dengan peraturan perundang-undangan yang berlaku seperti yang dijelaskan pada Pasal 6 Undang-Undang No. 13 Tahun 2006 tentang Perlindungan Saksi dan Korban; b. Ganti kerugian yang diberikan oleh pelaku sesuai dengan ketentuan Pasal 7 ayat (1) huruf b Undang-Undang Nomor 13 Tahun 2006 tentang Perlindungan Saksi dan Korban; c. Restitusi, ganti kerugian yang diberikan negara karena pelaku tak mampu. dimungkinkan sebagai upaya pemberian pelayanan pada para korban kejahatan dalam rangka mengembangkan kesejahteraan dan keadilan sesuai dengan ketentuan Pasal 7 ayat (2) UndangUndang Nomor 13 Tahun 2006 tentang Perlindungan Saksi dan Korban.
\end{abstract}

Kata-kata Kunci : Legalisasi hukum; aborsi; korban perkosaan 


\section{Pendahuluan}

Masalah aborsi adalah isu kontroversial karena aborsi tidak hanya terkait dengan masalah medis, tetapi juga erat kaitannya dengan masalah kesehatan, etika moral, agama, dan hukum. Adanya perbedaan pendapat yang terjadi di kalangan ulama erat kaitannya dengan masalah aborsi yang non therapeucitus pada usia 120 hari. Sebagian mereka ada yang memperbolehkan, memakruhkan, bahkan sebagian mengharamkan. ${ }^{1}$ Perdebatan agama dan etika, nilai-nilai yang hidup dalam masyarakat memiliki nilai pembenaran masing-masing. Itulah mengapa sikap pro choice dan pro life dalam aborsi, saat ini masing-masing memiliki argumen yang dapat dibenarkan dalam perspektif masing-masing. ${ }^{2}$

Terkait permasalahan aborsi, gerakan pro-life dan pro-choice ini terdapat di negara-negara di dunia, termasuk Indonesia. Gerakan pro-life berpandangan bahwa hidup itu berharga, mulia, dan merupakan anugerah dari Tuhan. Kehidupan manusia itu dimulai sejak konsepsi, pertemuan ovum, dan sperma dalam kandungan. Saat itulah telah ada nyawa. Tindakan aborsi/menggugurkan janin dalam rahim sama saja dengan membunuh. Aborsi juga berarti melawan kekuasaan Tuhan. Sedangkan gerakan pro-choice berpandangan bahwa seorang wanita mempunyai hak penuh atas kesehatan reproduksinya dan kebebasan penuh untuk memutuskan apakah dia akan menghentikan kehamilannya atau tidak. $^{3}$

Data dari International Planed Parenthood Federation (IPPF) menyatakan dari 1000 perempuan ada 32-46 melakukan aborsi. Sedangkan menurut World Health Organization (WHO), 15\% dari kehamilan akan berakhir dengan keguguran spontan, maka hal ini menyatakan bahwa di Indonesia terdapat 15-20 di antara 100 kehamilan diakhiri dengan pengguguran sengaja. Konon di Jakarta saja setiap harinya sekitar 50-70 melakukan permintaan untuk pengguguran janin dan terdapat satu klinik di Surabaya yang dikelola oleh dua orang dokter terungkap sudah melakukan 300 pengguguran janin. ${ }^{4}$

Dunia seolah-olah dibuat marah dengan penegakkan hukum yang demikian. Seorang anak yang harusnya masih menempuh pendidikan mengalami perkosaan, lalu mendekam di penjara. Hal ini serasa pribahasa bagaikan jatuh tertimpa tangga kemudian. Anak-anak yang mengalami kekerasan, pelecehan,

1 Dewani Romli, "Aborsi dalam Perspektif Hukum Positif dan Hukum Islam (Suatu Kajian Komparatif)”, Jurnal AL-AD ALAH Vol. X, No. 2, Juli 2011, hlm. 157.

2 Aroma Elmina Martha dan Singgih Sulaksana, Legalisasi Aborsi, UII Press, Yogyakarta, 2019, hlm. 1.

3 Aroma Elmina Martha dalam Fransiska Maryanti, Lembar Fakta: Aborsi dalam Perspektif Agama dan HAM, Universitas Indonesia, Jakarta, hlm. 3.

${ }^{4}$ Sun Choirol Ummah, “Tindakan Aborsi Di Indonesia Menurut Hukum Islam”, Jurnal MKU UNY, hlm. 2. 
dan bahkan perkosaan mendapatkan perlindungan bukan malah dikejar-kejar oleh oknum aparat kepolisian yang akhirnya dijerat dengan pasal-pasal pidana akibat aborsi tersebut. Aborsi terhadap kehamilan hasil pemerkosaan masih menjadi kontroversi yang dewasa ini masih pelik untuk dipecahkan. Oleh karena itu penulis tertarik untuk mengkaji penelitian ini lebih dalam dengan judul "Kajian Yuridis Legalisasi Aborsi bagi Korban Tindak Pidana Pemerkosaan dalam Perspektif Hukum Positif".

\section{Rumusan Masalah}

Dari latar belakang di atas, maka permasalahan pada penelitian ini adalah sebagai berikut: pertama, bagaimana legalisasi aborsi bagi korban tindak pidana pemerkosaan dalam perspektif hukum positif? Kedua, bagaimana perlindungan hukum bagi dokter dan pasien dalam yang melakukan tindakan aborsi?

\section{Tujuan Penelitian}

Adapun tujuan dari penelitian ini adalah sebagai berikut : Pertama, untuk mengkaji dan mengetahui tentang legalisasi aborsi bagi korban tindak pidana pemerkosaan dalam perspektif hukum positif. Kedua, untuk mengkaji dan mengetahui tentang perlindungan hukum bagi dokter dan pasien dalam tindakan aborsi.

\section{Metode Penelitian}

Penelitian ini merupakan penelitian hukum normatif/doktrinal ${ }^{5}$ yang mengkaji kaidah perundang-undangan, mengkaji, dan mengetahui tentang legalisasi aborsi bagi korban tindak pidana pemerkosaan dalam perspektif hukum positif dan hukum Islam serta tentang perlindungan hukum bagi dokter dan pasien dalam tindakan aborsi. Sedangkan pendekatan yang digunakan adalah pendekatan perundang-undangan (statute approach) dan pendekatan perbandingan (comparative approach). ${ }^{6}$

${ }^{5}$ Soetandyo Wigjnosoebroto, Hukum, Paradigma, Metode dan Dinamika Masalahnya, HuMa, Jakarta, 2002, hlm. 147-176

${ }^{6}$ Uraian tentang pendekatan dalam penelitian hukum normatif, lihat Peter Mahmud Marzuki, Penelitian Hukum, Cetk. Kedua, Prenada Media, Jakarta, 2006. 


\section{Hasil Penelitian dan Pembahasan}

\section{Legalisasi Aborsi bagi Korban Tindak Pidana Pemerkosaan dalam Perspektif Hukum Positif dan Hukum Islam}

Pemerkosaan adalah suatu perbuatan seseorang yang secara paksa hendak melampiaskan nafsu seksualnya yang dapat dilihat sebagai pelanggaran normanorma dan tertib sosial. ${ }^{7}$ Tindak persetubuhan yang dilakukan oleh seorang lakilaki terhadap perempuan yang bukan istrinya dan tanpa persetujuannya dapat menimbulkan perlawanan. ${ }^{8}$ Pemerkosaan akan menimbulkan derita fisik, psikis, dan sosial pada korbannya. Selain itu, perkosaan dapat pula mengakibatkan kehamilan yang tidak diinginkan oleh korbannya. ${ }^{9}$ Dalam konteks ini terkadang ditempuh tindakan aborsi untuk mengatasi kehamilan yang tidak diinginkan tersebut.

Pada dasarnya aborsi adalah perbuatan yang dilarang. Aborsi (Abortus) dalam KUHP dikenal dengan istilah pengguguran kandungan. Perbuatan ini diatur melalui Pasal 299, 346, 347, 348, dan 349 KUHP. Pasal-pasal ini secara jelas dan tegas mengatur larangan melakukan aborsi dengan alasan apapun, termasuk aborsi karena alasan darurat (terpaksa) yaitu sebagai akibat perkosaan, baik bagi pelaku ataupun yang membantu melakukan aborsi. Bahkan dengan sanksi pidana yang berat apabila dilakukan oleh ahli medis. ${ }^{10}$

Hal serupa diatur juga dalam Undang-Undang Nomor 36 Tahun 2009 tentang Kesehatan (UU Kesehatan) Pasal 75 ayat (1) yang berbunyi "Setiap orang dilarang melakukan aborsi". Namun terdapat pengecualian dalam Pasal 75 ayat (2) yang berbunyi "Larangan sebagaimana dimaksud pada ayat (1) dapat dikecualikan berdasarkan a) indikasi kedaruratan medis yang dideteksi sejak usia dini kehamilan, baik yang mengancam nyawa ibu dan/atau janin, yang menderita penyakit genetik berat dan/atau cacat bawaan, maupun yang tidak dapat diperbaiki sehingga menyulitkan bayi tersebut hidup di luar kandungan atau; b) kehamilan akibat perkosaan yang dapat menyebabkan trauma psikologis bagi korban perkosaan. Kemudian, Pasal 75 ayat (3) UU Kesehatan berbunyi "Tindakan sebagaimana dimaksud pada ayat (2) hanya dapat dilakukan setelah melalui konseling dan/atau penasehatan pra tindakan dan diakhiri dengan

7 Abdul Wahid dan Muhammad Irfan, Perlindungan terbadap Korban Kekerasan Seksual Advokasi dan Hak Asasi Perempuan, Cetakan Pertama, Refika Aditama, Bandung, 2011, hlm. 40.

${ }^{8}$ Topo Santoso, Seksualitas dan Hukum Pidana, IND. HLL-CO, Jakarta, 1997, hlm. 17.

9 Suryono Ekotama, Harum Pudjiarti RS, dan G. Widiartama, Abortus Provocatus Provocatus bagi Korban Perkosaan Persepektif Viktimologi, Kriminologi dan Hukum Pidana, Ctk. Pertama, Universitas Atma Jaya, Yogyakarta, 2001, hlm. 33.

10 Tanti Kirana Utami \& Aji Mulyana, "Tanggung Jawab Dokter dalam Melakukan Aborsi Tanpa Seijin Ibu yang Mengandung atau Keluarga dalam Perspektif Hukum Positif di Indonesia”, Jurnal Mimbar Justitia, Vol. I No. 02, Edisi Juli-Desember 2015, hlm. 505. 
konseling pasca tindakan yang dilakukan oleh konselor yang kompeten dan berwenang".

Pasal 76 UU Kesehatan menyatakan bahwa "Aborsi sebagaimana dimaksud Pasal 75 hanya dapat dilakukan: a. Sebelum kehamilan berumur 6 minggu dihitung dari hari pertama haid terakhir, kecuali dalam hal kedaruratan medis; $b$. Oleh tenaga kesehatan yang memiliki keterampilan dan kewenangan yang memiliki sertifikat yang ditetapkan oleh menteri; c. Dengan persetujuan ibu hamil yang bersangkutan; d. Dengan izin suami, kecuali korban perkosaan; dan e. Penyedia layanan kesehatan yang memenuhi syarat yang ditetapkan oleh Menteri.

Berdasarkan ketentuan yang terdapat dalam UU Kesehatan jika kita kaitkan dengan aborsi karena kehamilan akibat perkosaan, maka dapat disimpulkan bahwa secara umum praktik aborsi dilarang, namun larangan tersebut dikecualikan pada beberapa keadaan seperti kehamilan akibat perkosaan. Tindakan medis terhadap aborsi akibat perkosaan hanya dapat dilakukan apabila: 1) Setelah melalui konseling dan/atau penasehatan pra tindakan dan diakhiri dengan konseling pasca tindakan yang dilakukan oleh konselor yang kompeten;

2) Dilakukan sebelum kehamilan berumur 6 minggu dihitung dari hari pertama haid terakhir, kecuali dalam hal kedaruratan medis;

3) Oleh tenaga kesehatan yang memiliki keterampilan dan kewenangan yang memiliki sertifikat yang ditetapkan oleh menteri;

4) Dengan persetujuan ibu hamil yang bersangkutan; dan

5) Penyedia layanan kesehatan yang memenuhi syarat yang ditetapkan oleh Menteri.

Selain itu, tindakan aborsi diatur lebih lanjut dalam aturan pelaksana yaitu melalui Pasal 31 Peraturan Pemerintah Nomor 61 Tahun 2014 tentang Kesehatan Reproduksi (PP Kesehatan Reproduksi) yang menyatakan bahwa aborsi hanya dapat dilakukan berdasarkan indikasi kedaruratan medis dan kehamilan akibat perkosaan.

Pernyataan di atas sesuai dengan Fatwa Majelis Ulama Indonesia (MUI). Fatwa ini menjelaskan bahwa aborsi boleh dilakukan untuk korban perkosaan, sesuai dengan penetapan kedua sebab sebagiaman tertuang dalam PP Kesehatan Reproduksi. Adapun bunyi fatwa MUI menyatakan bahwa "Keadaan hajat yang berkaitan dengan kehamilan yang dapat membolehkan aborsi adalah: 1). Janin yang dikandung dideteksi menderita cacat genetik yang kalau lahir kelak sulit disembuhkan; 2). Kehamilan akibat perkosaan yang ditetapkan oleh tim yang 
berwenang yang di dalamnya terdapat antara lain keluarga korban, dokter, dan ulama. ${ }^{11}$

Apabila melihat rumusan Pasal 75 UU Kesehatan tampaklah dengan jelas bahwa undang-undang tersebut melarang aborsi kecuali untuk jenis aborsi provocatus therapeuticus (aborsi yang dilakukan untuk menyelamatkan jiwa si ibu dan atau janinnya). Dalam dunia kedokteran, aborsi provocatus medicalis dapat dilakukan jika nyawa si ibu terancam bahaya maut akibat dari lahirnya bayi yang belum waktunya ataupun keadaan si ibu yang mengandung sebelum melahirkan mengalami masalah kesehatan yang menyangkut, Iatrogenik, maternal, uterus, plasenta, cairan amnion, janin, dan serviks. ${ }^{12}$

Keberadaan UU Kesehatan, selain memberikan jaminan untuk profesionaitas bagi tenaga medis juga membawa angin segar yang berupa hak bagi perempuan dan anak perempuan yang hamil akibat korban pemerkosaan sebagaimana tertuang dalam Pasal 75 UU Kesehatan. Kini pemerintah telah menerbitkan Peraturan Pemerintah Nomor 61 Tahun 2014 tentang Kesehatan Reproduksi (PP Kesehatan Reproduksi) sebagai pelaksana teknis dari UU Kesehatan. Ketentuan legalistas aborsi terhadap kehamilan akibat perkosaan ini diperkuat dalam Pasal 31 ayat (1) PP Kesehatan Reproduksi yang antara lain menyatakan bahwa tindakan aborsi hanya dapat dilakukan apabila usia kehamilan paling lama berusia 40 hari dihitung sejak pertama haid terakhir. Kemudian dalam Pasal 34 ayat (2) PP Kesehatan Produksi menyatakan kehamilan akibat perkosaan itupun harus dibuktikan dengan:13

a. Usia kehamilan sesuai dengan kejadian perkosaan, yang dinyatakan oleh surat keterangan dokter; dan

b. Keterangan penyidik, psikologi, dan/atau ahli lain mengenai aborsi dugaan perkosaan.

Aborsi kehamilan akibat perkosaan harus dilakukan dengan aman, bermutu, dan bertanggung jawab sebagaimana disebutkan dalam Pasal 35 ayat (1) PP Kesehatan Reproduksi. Di samping itu, hak-hak wanita korban/perempuan dan anak perempuan perkosaan yang ingin melakukan aborsi tercermin dalam pengaturan Pasal 37 PP Kesehatan Reproduksi yaitu tindakan aborsi berdasarkan kehamilan akibat perkosaan hanya dapat dilakukan melalui konseling dan pasca konseling. Adapun tujuan pra konseling adalah: ${ }^{14}$

${ }^{11}$ Indonesia, Majelis Ulama Indonesia Nomor 4 Tahun 2005 tentang Aborsi.

12 Noroyono Wibowo, Penanganan Mutakhir Bayi Prematur: Memenubi Kebutuban Bayi Prematur untuk. Menunjang Peningkatan Kualitas Sumber Daya Manusia, Fakultas Kedokteran UI, Jakarta, 1997, hlm. 2.

13 Siska Lis Sutiani, Kejahatan \& Penyimpangan Seksual dalam Perspektif Hukum Islam dan Hukum Positif Indonesia, Cetakan Pertama, Nuasa Aulia, Bandung, 2016, hlm. 110.

${ }^{14}$ Lihat Pasal 37 ayat (3) Peraturan Pemerintah No. 61 Tahun 2014 tentang Kesehatan Reproduksi. 
1. Menjajaki kebutuhan dari perempuan yang ingin melakukan aborsi.

2. Menyampaikan dan menjelaskan kepada perempuan yang ingin melakukan aborsi bahwa tindakan aborsi dapat atau tidak dapat dilakukan berdasarkan hasil pemeriksaan penunjang.

3. Menjelaskan tahapan tindakan aborsi yang dilakukan dan kemungkinan efek samping atau komplikasinya.

4. Membantu perempuan yang ingin melakukan aborsi untuk mengambil keputusan sendiri untuk melakukan aborsi setelah mendapatkan informasi mengenai aborsi.

5. Menilai kesiapan pasien untuk menjalani aborsi.

Sedangkan konseling pasca tindakan aborsi dilakukan dengan tujuan: 15

1. Mengobservasi dan mengevaluasi kondisi pasien setelah tindakan aborsi.

2. Membantu pasien memahami keadaan atau kondisi fisil setelah menjalani aborsi.

3. Menjelaskan perlunya kunjungan ulang untuk pemeriksaan dan konseling lanjutan atau tindakan rujukan bila diperlukan, dan

4. Menjelaskan pentingnya penggunaan alat kontrasepsi untuk mnecegah terjadinya kehamilan.

Selanjutnya disebutkan dalam Pasal 38 ayat (1) PP Kesehatan Reproduksi bahwa dalam hal korban perkosaan memutuskan membatalkan keinginan untuk melakukan aborsi setelah mendapatkan informasi mengenai aborsi atau tidak memenuhi ketentuan untuk dilakukan tindakan aborsi, korban pemerkosaan dapat diberikan pendampingan oleh konselor selama masa kehamilan.16

Permasalahan yang terjadi pada korban perkosaan adalah korban pada umumnya mengalami trauma dan tidak segera menceritakan peristiwa yang dialaminya kepada keluarga atau orang lain yang dapat membantunya untuk segera dilakukan tindakan medis penggunaan kontrasepsi darurat sebagi usaha pencegahan risiko kehamilan dan/atau melaporkan kepada kepolisian. Korban pada umumnya merasa takut mengungkapkan apa yang telah terjadi pada keluarga, sehingga ia cenderung akan melakukan self blaming yang justru akan semakin memperburuk keadaannya. Hal inilah yang membuat korban menutup diri untuk menceritakan perkosaan yang dialami kepada orang-orang di sekitarnya karena rasa takut menerima label buruk dari lingkungan. Dengan demikian, korban akan menarik diri dari lingkungan karena merasa tidak mampu kembali berinteraksi sosial dengan masyarakat secara normal dan takut

\footnotetext{
${ }^{15}$ Lihat Pasal 37 ayat (4) Peraturan Pemerintah No. 61 Tahun 2014 tentang Kesehatan Reproduksi

${ }^{16}$ Aroma Elmina Martha dan Singgih Sulaksana, Legalisasi Aborsi ..., Op. Cit., hlm. 140.
} 
dikucilkan oleh orang lain di lingkungan sekitarnya karena dianggap membawa aib. ${ }^{17}$

Prosedural untuk diperbolehkan melakukan tindakan aborsi bagi perempuan korban pemerkosaan di antaranya harus terpenuhinya surat keterangan dari dokter yaitu hasil visum et repertum yang dikeluarkan oleh dokter setelah adanya pemeriksaan, apakah benar atau tidak jika perempuan tersebut telah mengalami tindak pidana perkosaan. Setelah itu, syarat kedua adalah keterangan dari penyidik yang telah melakukan penyelidikan, apakah benar atau tidak jika ada tindak pidana perkosaan yang dilakukan kepada seorang perempuan tersebut. Seorang penyidik untuk menyelesaikan perkara perkosaan yang tergolong mudah bisa memerlukan waktu 38 hari dan dapat diperpanjang apabila penyidikan belum selesai. Namun, keterangan dari penyidik juga belum bisa dikatakan bahwa seseorang telah melakukan tindak pidana perkosaan sebelum adanya keputusan hakim di pengadilan yang tetap (inkracht).

Pada masyarakat Indonesia, aborsi dilarang atau dipersulit oleh undangundang. Perempuan hamil biasanya meminta bantuan dukun atau orang lain yang tidak kompeten. Perbuatan ini justru dapat menimbulkan komplikasi seperti infeksi, pendarahan yang hebat, kemandulan, bahkan kematian perempuan yang bersangkutan. Perempuan tersebut dapat meminta bantuan dokter ahli, tetapi karena perbuatan terlarang yang dapat menimbulkan risiko bagi dokter tersebut, perempuan yang bersangkutan akan dikenakan pembayaran yang sangat mahal. ${ }^{18}$

Aborsi sebagai salah satu pilihan pada korban yang hamil karena perkosaan telah diakomodir melalui Undang-Undang No. 39 Tahun 2009 tentang Kesehatan. Namun dalam implementasinya, banyak korban tidak memahami dan tenaga medis di rumah sakit pemerintah yang enggan untuk menangani.

Aborsi menjadi salah satu aspek yang menyangkut kesehatan reproduksi. Apabila mengacu pada Pasal 70 ayat (1) UU Kesehatan, kesehatan reproduksi merupakan keadaan sehat secara fisik, mental, dan sosial secara utuh, tidak semata-mata bebas dari penyakit atau kecacatan yang berkaitan dengan sistem, fungsi, dan proses reproduksi pada laki-laki dan perempuan. Kesehatan reproduksi mencakup kesehatan reproduksi perempuan. Menurut Pasal 70 ayat (2) UU Kesehatan, “Kesehatan reproduksi meliputi: a) saat sebelum hamil, hamil, melahirkan, dan sesudah melahirkan; b) pengaturan kehamilan, alat kontrasepsi, dan kesehatan seksual; dan c) kesehatan sistem reproduksi".

17 Riza Yuniar Sari, “Aborsi Korban Pemerkosaan Perspektif Hukum Islam dan Hak Asasi Manusia” dalam Al Hukama The Indonesian Journal of Islamic Family Law, Volume 03, Sidoarjo, hlm. 36.

18 Tina Asmarawati, Hukum \& Abortus, Cetakan Pertama, Deepublish, Yogyakarta, 2013, hlm. 2. 
Undang-Undang Nomor 26 Tahun 2000 tentang Hak Asasi Manusia mengatur perihal hak perempuan salah satunya tentang jaminan hak reproduksi perempuan, yaitu Pasal 49 ayat (3) menyebutkan: "Hak khusus yang melekat pada diri perempuan dikarenakan fungsi reproduksinya, dijamin dan dilindungi oleh hukum."

Undang-undang mengakui bahwa setiap orang memiliki hak-hak reproduksi, sebagaimana diatur dalam Pasal 72 UU Kesehatan. Hak-hak reproduksi merupakan hak asasi manusia dan dijamin oleh undang-undang. Hak-hak reproduksi tersebut mencakup ${ }^{19}$ :

a. menjalani kehidupan reproduksi dan kehidupan seksual yang sehat, aman, serta bebas dari paksaan dan/atau kekerasan dengan pasangan yang sah.

b. menentukan kehidupan reproduksinya dan bebas dari diskriminasi, paksaan, dan/atau kekerasan yang menghormati nilai-nilai luhur yang tidak merendahkan martabat manusia sesuai dengan norma agama.

c. menentukan sendiri kapan dan berapa sering ingin bereproduksi sehat secara medis serta tidak bertentangan dengan norma agama

d. memperoleh informasi, edukasi, dan konseling mengenai kesehatan reproduksi yang benar dan dapat dipertanggungjawabkan.

Berdasarkan uraian di atas, maka kehamilan yang tidak dikehendaki akibat perkosaan adalah melanggar hak-hak reproduksi korban perkosaan sebagaimana disebutkan dalam Pasal 72 UU Kesehatan. Korban perkosaan kehilangan hak-hak reproduksinya serta kesehatan reproduksinya, baik secara fisik, mental dan sosial. Seharusnya setiap perempuan berhak menentukan kehidupan reproduksinya secara bebas, termasuk berhak menentukan kehamilannya sendiri. Dengan demikian, sangatlah pantas aborsi legal namun bersyarat bagi perempuan yang hamil akibat perkosaan mendapatkan jaminan dan perlindungan hukum terhadap hak-hak reproduksi korban.

Semua pihak dihadapkan pada adanya pertentangan, baik secara moral dan kemasyarakatan dalam dimensi agama dan hukum. Dari sisi moral dan kemasyarakatan, sulit untuk membiarkan perempuan harus merawat kehamilan yang tidak diinginkan karena hasil pemerkosaan. Melakukan aborsi pasti merupakan keputusan sangat berat yang diambil oleh korban. Tapi apabila perbuatan tersebut merupakan jalan yang terakhir, maka hal yang harus diperhatikan adalah persiapan secara fisik, mental, dan informasi yang cukup mengenai prosedur yang tepat agar aborsi bisa berlangsung aman.

Banyaknya kematian akibat aborsi yang tidak aman, tentu sangat memprihatinkan. Hal ini mengingat korban sangat takut akan larangan aborsi dan menganggap bahwa aborsi di rumah sakit yang akan diketahui oleh penegak

${ }^{19}$ Soekidjo Notoatmojo, Etika dan Hukum Kesehatan, Rineka Cipta, Jakarta, 2010, hlm. 134. 
hukum akan membawa mereka ke meja hijau. Dengan demikian, pilihan aborsi illegal melalui dukun atau penggunaan pil sering dilakukan. Hal ini diakibatkan kurangnya informasi dari perempuan dan masyarakat tentang hak atas pelayanan kesehatan. Padahal bagaimanapun kondisinya atau akibat apapun, setiap perempuan sebagai warga negara tetap memiliki hak untuk mendapatkan pelayanan kesehatan yang memadai sebagai bentuk kewajiban negara.

\section{Perlindungan Hukum bagi Dokter dan Pasien dalam Tindakan Aborsi}

Salah satu hak pasien adalah mendapatkan informasi sejeles-jelasnya dan selengkap-lengkapnya dari dokter yang menangani penyakitnya. Ini merupakan hak atas informasi yang merupakan bagian dari hak untuk menentukan nasibnya sendiri (the right of self determination). Hak ini merupakan salah satu hak dasar individu yang dimiliki oleh seorang pasien. Dalam hukum kesehatan, hubungan dokter dengan pasien diatur dalam Peraturan Menteri Kesehatan No. 290 Tahun 2008 tentang Persetujuan Tindakan Kedokteran terjalin dalam Ikatan Transaksi Terapeutik. Hubungan tersebut memberikan pemaknaan bahwa pihak yang satu memberi pelayanan dan pihak lain menerima pelayanan tersebut. Dalam ikatan demikianlah masalah persetujuan tindakan medik atau yang sekarang disebut persetujuan tindakan kedokteran timbul. Pihak dokter mempunyai kewajiban untuk melakukan diagnosis, pengobatan, dan tindakan medik yang terbaik menurut jalan fikiran dan pertimbangan mereka. Di sisi lain, pihak pasien atau keluarga pasien memiliki hak untuk menentukan persetujuan atau penolakan terhadap pengobatan atau tindakan medik yang dilaluinya. ${ }^{20}$

Persetujuan tindakan kedokteran adalah terjemahan yang dipakai untuk informed consent. Peraturan Menteri Kesehatan No. 290 Tahun 2008 menjelaskan bahwa persetujuan tindakan kedokteran adalah persetujuan yang diberikan pasien atau keluarga terdekat setelah mendapat penjelasan secara lengkap mengenai tindakan kedokteran atau kedokteran gigi yang akan dilakukan terhadap pasien. Lalu Komawalati berpendapat, Informed Consent adalah suatu kesepakatan/persetujuan pasien atas upaya medis yang akan dilakukan oleh dokter terhadap dirinya, setelah pasien mendapatkan informasi dari dokter mengenai upaya medis yang dapat dilakukan untuk menolong dirinya, disertai informasi mengenai segala resiko yang meungkin terjadi.21 Informed Consent dibuat dengan tujuan untuk:22

a. Memberikan perlindungan kepada pasien atas segala tindakan medis, dan

${ }^{20}$ M.Jusuf Hanafiah, Etika Kedokteran dan Hukum Kesehatan, EGC, Jakarta 2017, hlm. 93.

21 Desritza Ratman, Aspek Hukum Informed Consent dan Rekam Medis dalam Transaksi Terapeutik, Cetakan Pertama, Bandung, Keni Media, 2013, hlm. 106.

${ }^{22}$ Hendrik, Etika \& hukum Kesehatan, Kedokteran EGC, Jakarta, 2015, hlm. 59. 
b. Memberikan perlindungan tenanga kesehatan (dalam hal ini dokter-pen) terhadap terjadinya akibat yang tidak terduga yang dianggap merugikan pasien.

Selain Informed Consent, dalam pelayanan kesehatan dikenal dengan istilah Informed Choice. Informed Choice adalah membuat pilihan setelah mendapatkan penjelasan dari dokter tentang alternatif tindakan medis yang akan diberikan. Choice berarti adanya alternatif pilihan dan pasien mengerti perbedaannya, sehingga ia dapat menentukan mana yang disukai atau yang disesuaikan dengan kebutuhannya.

PP No. 61 Tahun 2014 tentang Kesehatan Reproduksi disebutkan bahwa dalam hal perempuan hamil tidak dapat memberikan persetujuan, maka persetujuan aborsi dapat diberikan oleh keluarga yang bersangkutan. Kemudian dalam hal ini suami tidak dapat dihubungi, izin diberikan oleh keluarga yang bersangkutan. Berdasarkan pasal-pasal tersebut diketahui bahwa persetujuan aborsi yang diberikan oleh ibu hamil atau suami/keluarganya tersebut merupakan informed consent. Hal ini berarti ibu hamil atau suami/keluarganya telah menyetujui untuk dilakukan tindakan aborsi terhadap kandungannya, setelah mendapat informasi dari tim dokter.

Namun, aborsi kehamilan perkosaan bertentangan dengan sumpah dokter dengan terbitnya PP Kesehatan Reproduksi yang menambahkan aturan legislasi aborsi kehamilan akibat perkosaan. Hal tersebut menimbulkan kontroversi terutama di kalangan dokter. Ketua Ikatan Dokter Indonesia (IDI), Zaenal Abidin menilai PP No. 61 Tahun 2014 tentang Kesehatan Reproduksi perlu dikaji kembali, khususnya untuk praktik aborsi. Menurutnya PP tersebut bertentangan dengan Kitab Undang-Undang Hukum Pidana, Bab Kejahatan terhadap nyawa dan bertentangan dengan sumpah dokter. Zaenal menambahakan jika PP tersebut diberlakukan, KUHP juga tetap masih berlaku, sehingga meskipun ada payung hukum sekalipun, dokter sangat beresiko menerima hukuman dan dipenjarakan apabila melakukan praktik aborsi.

Berdasarkan analisa penulis, dengan melihat fenomena sekarang untuk indikasi kedaruratan medis tidak menjadi permasalahan yang rumit. Hal ini dikarenakan bahwa dalam kedokteran abortus provocatus medicalinas atau aborsi atas indikasi kedaruratan medis merupakan tindakan medis aborsi yang harus dilaksanakan terhadap ibu hamil dalam kondisi darurat. Keadaan demikian apabila tidak dilaksanakan aborsi, maka dapat mengancam nyawa ibu hamil tersebut. Adanya kehamilan atas tindakan perkosaan dengan melihat segala aturan-aturan yang ada di hukum positif secara keseluruhan memberatakan tindakan tersebut. Dengan demikian, penulis berpendapat untuk kehamilan 
akibat perkosaan untuk dibuktikan terlebih dahulu karena jika tidak ada unsur pembuktian maka kemudahan dalam aborsi kehamilan bisa disalahgunakan oleh perempuan-perempuan yang telah hamil dan bisa saja menggunakan alasan ataupun dalih perkosaan padahal sejatinya mereka mengalami kehamilan karena alasan lain.

\section{Penutup}

Berdasarkan pemaparan di atas, penulis memberikan kesimpulan yaitu pertama, bahwa Pasal 283, 299, 346-349 KUHP menyatakan adanya pelarangan terhadap aborsi. Namun terdapat pengecualian yang termuat dalam UndangUndang No. 36 Tahun 2009 tentang Kesehatan yakni larangan tersebut dikecualikan berdasarkan indikasi kedaruratan medis dan kehamilan akibat perkosaan. Ketentuan tersebut diatur lebih lanjut dalam Pasal 31 ayat (2) PP No. 61 Tahun 2014 tentang Kesehatan Reproduksi, yang menyebutkan bahwa tindakan aborsi karena kehamilan akibat perkosaan hanya daat dilakukan apabila usia kehamilan paling lama 40 hari dihitung sejak hari pertama haid terakhir. Kemudian diperjelas kembali dalam Pasal 34 ayat (2) PP tersebut, bahwa kehamilan akibat perkosaan harus dibuktikan dengan surat keterangan dokter dan keterangan penyidik, psikolog, dan/atau ahli lain mengenai adanya dugaan perkosaan. Pasal 34 ayat (2) ini menjadi permasalahan hukum, apabila kehamilan yang terjadi akibat tindak pidana perkosaan hanya cukup dibuktikan dengan surat keterangan dokter, penyidik, psikolog dan/atau ahli lain.

Kedua, perlindungan hukum yang dapat menangani dan mengurangi kasus tersebut, berikut dijelaskan beberapa bentuk perlindungan hukum bagi korban perkosaan, yaitu sebagai berikut: a. Pemberian pelayanan bantuan medis dan psikososial kepada korban perkosaan yang melakukan aborsi sesuai dengan peraturan perundang-undangan yang berlaku seperti yang dijelaskan pada Pasal 6 Undang-Undang No. 13 Tahun 2006 tentang Perlindungan Saksi dan Korban; b. Ganti kerugian yang diberikan oleh pelaku sesuai dengan ketentuan Pasal 7 ayat (1) huruf b Undang-Undang Nomor 13 Tahun 2006 tentang Perlindungan Saksi dan Korban; c. Restitusi, ganti kerugian yang diberikan negara karena pelaku tak mampu. Dimungkinkan sebagai upaya pemberian pelayanan pada para korban kejahatan dalam rangka mengembangkan kesejahteraan dan keadilan sesuai dengan ketentuan Pasal 7 ayat (2) Undang-Undang Nomor 13 Tahun 2006 tentang Perlindungan Saksi dan Korban. Selain itu, perlindungan hukum bagi dokter yang membantu perempuan korban perkosaan dengan melakukan aborsi bertentangan dengan KUHP dan sumpah dokter, walaupun hal itu terdapat 
pengecualiaan pengaturan sebagaimana tertuang dalam PP No. 61 Tahun 2014 tentang Kesehatan Reproduksi.

\section{Daftar Pustaka}

\section{Buku}

Asmarawati, Tina, Hukum \& Abortus, Cetakan Pertama, Deepublish, Yogyakarta, 2013.

Ekotama, Suryono, Harum Pudjiarti RS, dan G. Widiartama, Abortus Provocatus Provocatus bagi Korban Perkosaan Persepektif Viktimologi, Kriminologi dan Hukum Pidana, Cet Pertama, Universitas Atma Jaya, Yogyakarta, 2001.

Elmina Martha, Aroma dan Singgih Sulaksana dalam Paulinus Soge, Hukum Aborsi: Tinjauan Politik Hukum Pidana Terhadap Perkembangan Hukum Aborsi di Indonesia, Cetakan ketiga Universitas Atma Jaya Yogyakarta, 2019.

Hanafiah, M. Jusuf, Etika Kedokteran dan Hukum Kesehatan, Penerbit Buku Kedokteran EGC, Jakarta, 2017.

Hendrik, Etika \& Hukum Kesehatan, Penerbit buku Kedokteran EGC, Jakarta, 2015.

Lis Sulistiani, Siska, Kejahtan \& Penyimpangan Seksual dalam Perspektif Hukum Islam dan Hukum Positif Indonesia, Cetakan Pertama, Nuansa Aulia, Bandung, 2016.

Mahmud Marzuki, Peter Penelitian Hukum, Cetk. Kedua, Prenada Media, Jakarta, 2006

Maryanti, Fransiska, Lembar Fakta: Aborsi dalam Perspektif Agama dan HAM, Universitas Indonesia, Jakarta.

Notoatmojo, Soekidjo, Etika dan Hukum Kesehatan, Rineka Cipta, Jakarta, 2010.

Rahardjo, Satjipto, Membedah Hukum Progresif, Cet. Ke-3, Penerbit Buku Kompas, Jakarta, 2008.

Santoso, Topo, Seksualitas dan Hukum Pidana, IND.HLL-CO, Jakarta, 1997.

Ratman, Desritza, Aspek Hukum Informed Consent dan Rekam Medis dalam Transaksi Terapeutik, Cetakan Pertama, Bandung, Keni Media, 2013.

Wahid, Abdul dan Muhammad Irfan, Perlindungan terhadap Korban Kekerasan Seksual Advokasi dan Hak Asasi Perempuan, Cetakan Pertama, Refika Aditama, Bandung, 2011.

Wibowo, Noroyono, Penanganan Mutakhir Bayi Prematur: Memenuhi Kebutuhan Bayi Prematur untuk Menunjang Peningkatan Kualitas Sumber Daya Manusia, Fakultas Kedokteran UI, Jakarta, 1997.

Wigjnosoebroto, Soetandyo, Hukum, Paradigma, Metode dan Dinamika Masalahnya, HuMa, Jakarta, 2002.

\section{Jurnal}

Riza Yuniar Sari, “Aborsi Korban Pemerkosaan Perspektif Hukum Islam dan Hak Asasi Manusia", Al Hukama The Indonesian Journal Of Islamic Family Law, Volume 03, Sidoarjo. 
Romli Dewani, "Aborsi Dalam Perspektif Hukum Positif Dan Hukum Islam (Suatu Kajian Komparatif )", Jurnal Al-Adalah, Vol. X, No. 2, Juli 2011.

Rosdianah, "Tinjauan Yuridis Tentang Perlindungan Pelaku Aborsi Korban Pemerkosaan Dalam Perspektif Viktimologi", Jurnal Ilmiah, Fakultas Hukum Universitas Mataram, Mataram, 2019.

Sun Choirol Ummah, "Tindakan Aborsi Di Indonesia Menurut Hukum Islam", Jurnal MKU UNY, Yogyakarta.

Tanti Kirana Utami, \& Mulyana, Aji, “Tanggung Jawab Dokter Dalam Melakukan Aborsi Tanpa Seijin Ibu Yang Mengandung Atau Keluarga Dalam Perspektif Hukum Positif di Indonesia", Jurnal Mimbar Justitia, Vol. I, No. 02, Edisi Juli-Desember 2015.

Wiwiek Afifah, "Perlindungan Hukum Bagi Perempuan Korban Perkosaan yang Melakukan Aborsi", Jurnal Ilmu Hukum, Februari 2013, Vol. 9, No. 18, 2013.

\section{Peraturan Perundang-Undangan}

Konvensi Penghapusan Segala Bentuk Diskriminasi terhadap Perempuan (Deklarasi Penghapusan Kekerasan Terhadap Perempuan dalam Majelis Umum Perserikatan Bangsa-Bangsa)

Undang-Undang Dasar Negara Republik Indonesia 1945

Undang-Undang No.7 Tahun 1984 tentang Ratifikasi Konvensi Penghapusan Segala Bentuk Diskriminasi terhadap Perempuan

Undang-Undang No. 39 Tahun 1999 tentang Hak Asasi Manusia

Undang-Undang No. 13 Tahun 2006 tentang Perlindungan Saksi dan Korban

Undang-Undang No. 36 Tahun 2009 tentang Kesehatan

Undang-Undang No. 1 Tahun 1946 tentang Kitab Undang-Undang Hukum Pidana (KUHP)

Undang-Undang No. 8 Tahun 1981 tentang Kitab Undang-Undang Hukum Acara Pidana (KUHAP)

Peraturan Pemerintah No. 61 Tahun 2014 tentang Kesehatan Reproduksi

Media Masa

https://www.bbc.com/indonesia/indonesia-45015083 